\title{
Dicionário do Teatro Brasileiro: temas, formas e conceitos de Jacó Guinsburg, João R. Faria \& Mariangela A. de Lima (coord.) São Paulo, Perspectiva, 2006.
}

\author{
Elizabeth R. Azevedo
}

oi lançado pela editora Perspectiva em parceria com o Sesc de São Paulo, em abril de 2006, o Dicionário do Teatro Brasileiro: temas, formas e conceitos. A coordenação do ambicioso projeto ficou a cargo de Jacó Guinsburg, professor da ECA/USP e editor da Perspectiva, João Roberto Faria, professor de Literatura Brasileira da Faculdade de Letras da USP e Mariangela Alves de Lima, crítica teatral do jornal $O$ Estado de S. Paulo e pesquisadora do teatro brasileiro.

A proposta da obra não é a de arrolar sistematicamente todo e qualquer termo referente ao teatro (relativos a equipamentos, por exemplo), mas sim a de registrar definições de práticas, funções e estilos, como indicado no subtítulo. Tentativas anteriores de se elaborar dicionários que abarcassem todos os aspectos da área teatral se mostraram por vezes incompletas ou superficiais. O Dicionário também não quis equiparar-se a uma enciclopédia com verbetes sobre autores, atores, grupos e espetáculos (como faz a Enciclopédia Itaú Cultural de Teatro, disponível on line no site do Instituto Itaú Cultural). Mesmo assim, através de um índice remissivo, é possível rastrear, por exemplo, quarenta e uma menções a Artur Azevedo, trinta e sete a Nelson Rodrigues ou ainda quarenta e três a Augusto Boal, entre muitos outros artistas e teóricos do teatro brasileiro.

O Dicionário do Teatro Brasileiro aborda temas, formas e conceitos presentes no universo teatral na medida em que esses se transformaram em fenômenos nacionais. Trata-se de registrar a recepção de tais eventos ao longo de cinco séculos da história teatral brasileira, tanto na área da dramaturgia quanto da encenação. Se em geral, a idéia de recepção se aplica à vinculação direta entre obra/leitor, no teatro essa relação é mediada pela atividade dos diversos profissionais que realizam os espetáculos. Assim, é possível pensar em sobreposições de recepções efetuadas por autores, tradutores, adaptadores, diretores, atores e público, cada um deles deixando sua marca na vida das obras e dos movimentos estéticos que aportaram por aqui. É portanto o registro de uma prática antropofágica ou tropicalista, como se queira. O próprio Dicionário, no verbete Antropofagia (Teatro e), escrito por Eudinyr Fraga, traz uma definição que pode ser aplicada à concepção que guiou a obra como um todo: uma linguagem literária que se caracterizava, não exatamente pela negação dos valores eruditos europeus, mas pela assimilação aos demais [existentes no Brasil], já fortemente enraizados na psique nacional. Se

Elizabeth R. Azevedo é Professora do Departamento de Artes Cênicas da ECA-USP. 
ampliarmos a abrangência dessa definição, alterando o termo literário para cênico e os valores europeus para valores universais, chegaremos bem perto do que se pode encontrar como reflexão sobre o teatro brasileiro adotada pelo Dicionário.

As incorporaçōes, transformaçōes, recriações e inovações feitas em terras brasileiras foram se configurando com o correr do tempo, através da contribuição de cada um dos envolvidos nesse processo. Assim, muito embora não tenha sido pensado como uma obra de caráter cronológico, marcada por entradas a partir de acontecimentos específicos, o Dicionário não deixa de apresentar um componente histórico fundamental. Pode-se passar de um verbete a outro relacionado, construindo-se uma linha de desenvolvimento ou mesmo marcando rupturas. É verdade que o fato de ser uma obra composta a muitas mãos transforma essa trajetória, por vezes, poucas felizmente, em um percurso acidentado.

A proporção entre a exposição mais geral de cada assunto abordado e o relato de seu desenvolvimento no Brasil varia segundo cada autor, ou, às vezes, em função do tema. $\mathrm{O}$ verbete Legislação Teatral, escrito por Amilton Monteiro, por exemplo, menciona rapidamente a influência da tradição jurídica portuguesa sobre conformação das diretrizes legais brasileiras, mas constitui-se, basicamente, num relato histórico que desvenda o emaranhado de alvarás, ordenações, leis e portarias que trataram do teatro nacional. Outros verbetes são ainda mais específicos da realidade teatral brasileira e, portanto, não fazem maiores referências a modelos externos. Estão nesse caso: teatro abolicionista, antropofagia, besteirol, brincante, sistema coringa, herói humilde, te-ato, apenas para citar alguns.

Ao todo, são 39 colaboradores que elaboraram 250 verbetes. De fato, o grande mérito do Dicionário do Teatro Brasileiro está justamente em ter contado com o conhecimento especializado de cada um desses professores, pesquisadores, críticos e artistas de todo o Brasil que tornaram cada uma das entradas (ou várias delas combinadas) uma pequena introdução aos tópicos tratados, completada com a indicação de bibliografia para quem quiser se aprofundar nos temas abordados. Desse modo, a obra transforma-se num registro sintético da crescente reflexão teórica e conhecimento histórico sobre o teatro brasileiro.

Tem destaque nesse rol de especialistas a contribuição do ex-professor de Teatro Brasileiro da ECA/USP, Eudinyr Fraga, que redigiu o maior número de verbetes referentes, entre outros, às pesquisas desenvolvidas por ele ao longo de sua carreira, tais como: o teatro simbolista e as obras dos dramaturgos Qorpo Santo e Nelson Rodrigues. Ana Maria Amaral é responsável por vinte e dois verbetes que cobrem praticamente todo o universo do teatro de animação, com inúmeros detalhes sobre tipos de bonecos que fazem parte da cultura popular de diversas regiôes brasileiras. Sobre o teatro musicado, tão importante na história da cena brasileira entre o final do século XIX e as primeiras décadas do $\mathrm{XX}$, tem-se os verbetes da professora e diretora Neyde Veneziano, autora de diversos livros sobre o assunto. João Roberto Faria e Mariângela Alves de Lima, além de coordenadores, também puseram mãos à obra contribuindo com inúmeras definições sobre formas da arte teatral.

A grande variedade de vozes presentes na obra se harmoniza com uma abordagem ampla do fenômeno teatral, pois nela são generosamente incorporadas aquelas manifestações que fazem fronteira com uma definição mais tradicional de teatro. Encontram-se verbetados temas relativos ao circo, às festas populares, às danças dramáticas, à música e aos formatos midiatizados da expressão dramática como: Tony de soirée, carnaval, bumba-meu-boi, cançoneta, radionovela, respectivamente, a tal ponto que se poderia pensar em chamar a publicação de dicionário de artes cênicas brasileiras.

Note-se, além disso, que estão representadas em diversos verbetes manifestaçôes que extrapolam as atividades realizadas no eixo RioSão Paulo, descortinando uma pouco divulga- 
da atividade teatral. Sob esse aspecto, vejam-se, por exemplo, as definições sobre pássaros juninos, teatro amador ou as diversas manifestações populares.

Finalmente, não se pode deixar de mencionar a presença de alguns conceitos ou práticas curiosos como: enterro, pateada, cabala, timbaleiro, e mesmo, merda.

Cabe perguntar se em uma obra de espectro tão amplo, redigida por reconhecidos conhecedores de suas áreas, seria possível sentir a falta de outros temas, formas ou conceitos? Talvez a resposta esteja no próprio Dicionário. No verbete cenografia, elaborado pelo cenógrafo J. C. Serroni, lê-se: Não se deve confundir cenografia com cenário. O cenário está dentro da cenografia, que é muito mais abrangente. Não seria interessante abrir um espaço extra para ter um verbete específico sobre cenário onde o conceito pudesse se desenvolver mais? O mesmo se dá com teatro de variedades mencionado em alguns verbetes, mas que não encontra uma definição própria.

Há alguns anos, a editora Perspectiva traduziu e lançou o Dicionário de Teatro, do professor da Universidade Paris VIII, Patrice Pavis, iniciativa de grande relevância para os brasileiros estudiosos de teatro. Contudo, a obra de Pavis - e daí, aliás, seu mérito - lista conceitos gerais comuns ao teatro universal. Ela foi, sem dúvida, uma referência para a edição do novo dicionário, que procurou ir além. O Dicionário do Teatro Brasileiro é fundamental para os estudiosos do teatro brasileiro, que sentem a falta de publicações amplas e gerais mais recentes. Além disso, as pesquisas monográficas na área teatral, oriundas da crescente atividade dos cursos de pós-graduação, geralmente enfrentam dificuldades para serem publicadas. Assim, o Dicionário cumpre a missão de arregimentar especialistas e pesquisadores para disseminar o conhecimento atual sobre o universo do nosso teatro. 